\title{
ASPEK ASPEK KEMANUSIAAN DALAM TERORISME BERDASARKAN KAJIAN FIKIH
}

\author{
Afifi Fauzi Abbas \\ Fakultas Syariah LAIN Bukittinggi \\ e-mail:afifi_abbas12@gmail.com \\ DOI: http:/ / dx.doi.org/10.30983/islam_realitas.v2i1.106
}

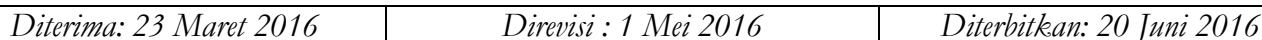

\begin{abstract}
Human right is the basic right possesed by all buman beings. This right does not need to be given, purchased or inherited. Human right is automatically part of human, and buman right is also applied to all mankind whoever the person, and does not rely on race, ethnicity or religion and age considerations. Humanitarian issues faced by Muslims in Indonesia today is the treatment of the country against terrorism suspects in raids in several cases considered terrorism cases in Indonesia starting from the Bali bombings, Bom Sarinab, and several other terrorism cases. Discuss about the bumanitarian aspect of terrorism is becoming a necessity, especially from the perspective of jurisprudence. In Islamic Figh, autopsy (forensic) can be done, and the results serve as evidence that the rules of evidence in Islam can be categorized as "witness", that is, those who heard the testimony, including expert testimony. In this case many verses of the Qur'an are ordered to give this testimony, especially for those who can provide it.
\end{abstract}

Keywords: Humanitarian, Terrorism, Fiqh

\section{Abstrak}

HAM adalah hak dasar atau hak asasi yang dimiliki semua manusia. Hak ini tidak perlu diberikan, dibeli ataupun diwarisi. HAM adalah bagian dari manusia secara otomatis, dan HAM juga berlaku untuk seluruh umat manusia siapapun orangnya, dan tidak bergantung pada pertimbangan RAS, etnis maupun agama dan usia. Persoalan kemanusian yang dihadapi umat Muslim di Indonesia saat ini adalah perlakuan negara terhadap tersangka terorisme dalam beberapa kasus penggerebekan dalam kasus yang dianggap terorisme di Indonesia mulai dari kasus Bom Bali, Bom Sarinah dan beberapa kasus terorisme lainnya. Membicarakan aspek aspek kemanusiaan dalam terorisme adalah menjadi sebuah keniscayaan, apalagi kalau dilihat dari perspektif fikih. Dalam pandangan fikih Islam autopsi (forensik) dapat dilakukan, dan hasilnya berfungsi sebagai alat bukti, yang dalam hukum pembuktian dalam Islam bisa dimasukkan ke dalam bukti "saksi", yaitu orang yang didengar keterangannya, termasuk di dalamnya keterangan ahli. Dalam hal ini banyak ayat al-Quran yang memerintahkan untuk memberikan kesaksian ini terutama bagi mereka yang sanggup memberikannya.

Kata Kunci: Kemanusiaan, Terorisme, Fikih.

\section{Latar Belakang}

Hakikat

penghormatan dan perlindungan terhadap Hak Asasi Manusia (HAM) adalah demi menjaga eksistensi manusia secara utuh melalui aksi keseimbangan antara hak dan kewajiban serta keseimbangan antara kepentingan perseorangan dan kepentingan umum. Secara konklutif, ini berarti HAM tidak perlu diberikan, dibeli ataupun diwarisi. HAM adalah bagian dari manusia secara otomatis (include), dan HAM juga berlaku untuk seluruh umat manusia siapapun orangnya, dan tidak bergantung pada pertimbangan RAS, etnis maupun agama dan usia. HAM juga tidak bisa dilanggar dan tidak seorangpun mempunyai hak untuk membatasi dan melanggar hak orang lain. 
Karena HAM sesungguhnya merupakan bagian dari hakikat kemanusiaan yang paling intrinsik, maka sejarah pertumbuhan konsepkonsepnya dan perjuangan menegakkannya sekaligus menyatu dengan sejarah manusia itu sendiri semenjak dikenalnya peradaban. Ini dapat dilihat dari ajaran agama-agama. Dalam agama Semitik/agama Ibrahimi (Yahudi, Kristen dan Islam), misalnya salah satu persoalan kemanusiaan yang paling dini diungkapkan melalui penuturan tentang peristiwa pembunuhan yang menyangkut dua anak lelaki Adam as dan Hawa - yaitu Qabil dan Habil. Peristiwa pembunuhan pertama sesama manusia ini menghasilkan dekrit Tuhan telah dijelaskan dalam al-Qur'an surat al-Maidah ayat 27-32 :

"Barang siapa yang membunuh seorang manusia, bukan karena orang itu (membunuh) orang lain, atau bukan karena membuat kerusakan dimuka bumi, maka seakan-akan dia telah membunuh manusia seluruhnya. Dan barang siapa yang memelihara kehidupan seorang manusia, maka seolah-olah dia telah memelihara kehidupan manusia semuanya. Dan sesungguhnya telah datang kepada mereka rasul-rasul Kami dengan (membawa) keterangan-keterangan yang jelas, kemudian banyak di antara mereka sesudah itu sungguh-sungguh melampaui batas dalam berbuat kerusakan dimuka bumi"

Hal ini sesungguhnya memberikan pesan moral kepada kita bahwa persoalan kemanusiaan adalah persoalan yang selalu tumbuh dan berkembang sepanjang perkembangan sejarah umat mnusia. Jadi masalah kemanusiaan ini telah tumbuh dan berkembang sejalan dengan pertumbuhan dan perkembangan sejarah peradaban umat manusia. Ia sama tuanya dengan sejarah umat manusia sendiri.

Dewasa ini dunia diramaikan dengan isu radikalisme yang berujung pada terorisme yang menjadi masalah penting bagi umat Islam Indonesia dewasa ini. Menurut Rokhmad, dua isu itu telah menyebabkan Islam dicap sebagai agama teror dan umat Islam dianggap menyukai jalan kekerasan suci untuk menyebarkan agamanya. Sekalipun anggapan itu mudah dimentahkan, namun fakta bahwa pelaku teror di Indonesia adalah seorang Muslim garis keras sangat membebani psikologi umat Islam secara keseluruhan ${ }^{1}$. Bahkan dalam penelitian Umar menjelaskan bahwa seakan-akan para pengebom Bali adalah mereka yang terdoktrinasi untuk menghalalkan segala cara dalam memenuhi tuntutan ideologis mereka ${ }^{2}$.

Membicarakan aspek aspek kemanusiaan dalam terorisme adalah menjadi sebuah keniscayaan, apalagi kalau dilihat dari perspektif fikih. Karena bagaimanapun perlakuan pihak kepolisian dalam memperlakukan tersangka atau terdakwa terorisme ini perlu menjadi bahan kajian. Oleh karena itu tulisan ini membahas bagaimana perspektif kajian fikih tentang aspek-aspek kemanusiaan dalam memperlakukan korban dugaan terorisme terutama pengurusan jenazah penanganan autopsi mayat teroris. $\mathrm{Hal}$ ini perlu dilakukan untuk menyikapi beberapa perlakuan yang kadang tidak manusia terhadap pelaku terorisme.

\section{Prinsip-prinsip Damai Ajaran Islam}

Salah satu karakteristik Ajaran Islam

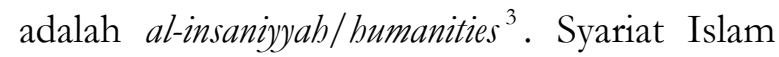

${ }^{1}$ Rokhmad, Abu, "Radikalisme Islam dan Upaya Deradikalisasi Paham Radikal", Walisongo: Jurnal Penelitian Sosial Keagamaan, Vol. 20, No. 1 2012, h. 79114.

2 Umar, Ahmad Rizky Mardhatillah, "Melacak Akar Radikalisme Islam di Indonesia", Jurnal Ilmu Sosial dan Ilmu Politik, 14.2. 2010, h. 169-186.

3 Karakteristik ajaran Islam seperti yang dijelaskan oleh Syekh Yusuf al-Qaradlawi, seluruhnya ada 6; Pertama, rabbaniyyah/teistik, kedua, akblaqiyyah/etis, ketiga, al-waqiiyyah/realistis, keempat, alinsaniyyah/bumanities-kemanusiaan, kelima, altanasuq/keteraturan, keenam, al-syumul/komprehensif. Cermati juga Yusuf al-Qaradlawi, Membumikan Syariat 
tersebut diciptakan untuk manusia agar derajatnya terangkat, sifat kemanusiaannya terjaga dan terpelihara, serta sifat kebinatangannya dapat dikekang. Manusia bukan hanya makhluk jasmani, tapi juga makhluk rohani. Syariat Islam menjaga kehormatan manusia yang tidak dapat dilakukan oleh siapapun, tetapi hanya dapat dilakukan oleh Sang Khaliq yang telah menetapkannya sebagai khalifah di muka bumi dan membuat para malaikat bersujud kepadanya.

Di samping itu prinsip hak asasi manusia dalam Islam menurut Asnawi dikenal istilah, "maqashid al-syariab" atau tujuan utama pemberlakuan syariat Islam, jika aturan-aturan tersebut diterapkan secara murni dan konsekuen, maka HAM setiap manusia di seluruh muka bumi ini akan terjamin. Perbedaan antara Islam dan Barat dalam memandang konsep HAM, yang pertama lebih bersifat religius (ketuhanan), sedangkan Barat lebih bersifat sekuler. Dunia Barat berorientasi hanya kepada manusia (pribadi), maka pertanggungjawabannya juga kepada manusia semata $^{4}$.

Syariat menjaga HAM dan kemuliaan ini dalam setiap aturan yang ditetapkan-Nya mulai dari sejak manusia dilahirkan sampai ia mati. Bahkan setelah matinya pun Islam masih memberikan penghormatan begitu tingginya sampai-sampai nabi melarang umatnya memecahkan tulang belulang manusia yang ditemukannya, sebagai ungkapan penghormatan yang begitu tinggi kepada yang namanya manusia. Hal ini memberi penegasan kepada kita bahwa Islam sangat memperhatikan aspek-aspek kemanusiaan ini

Islam, Keluwesan Aturan Ilabi Untuk Manusia (Bandung, Arasy Mizan, 2003), h. 94-161.

${ }^{4}$ Asnawi, Habib Shulton, "Hak Asasi Manusia Islam dan Barat (Studi Kritik Hukum Pidana Islam dan Hukuman Mati)", Jurnal Supremasi Hukum, Vol. 1, No. 1 2012, h. 12. termasuk kepada orang yang sudah mati/mayat.

\section{Pengurusan Jenazah Pelaku dan Terduga Pelaku Teror}

Salah satu hak Muslim sehingga menjadi kewajiban Muslim atas Muslim yang lainnya adalah mengurus jenazahnya. Banyak hadis Nabi yang memberikan pengarahan tentang itu, ada riwayat yang menggunakan redaksi اتجباع - mengikuti/mengiringi jenazah ${ }^{5}$, ada yang menggunakan redaksi شهود / menyaksikan - . Ulama-ulama fikih تجهيز

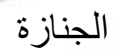

(mengurus-merawatmenyelenggarakan jenazah), dan hal ini dapat dicermati dalam kitab-kitab fikih mereka ketika membahas persoalan jenazah.

Terkait dengan hukum memandikan jenazah/mayat memang terdapat perbedaan pendapat di kalangan ulama fikih, ada yang mengatakan hukumnya wajib dan ada pula yang mengatakan sunnah saja. Penetapan hukum tersebut terkait dengan status yang melekat pada jenazah tsb, apakah jenazah tersebut jenazah seorang Muslim ataukah seorang kafir. Jika mayat seorang Muslim hukumnya tergantung dari kematiannya apakah ia matinya wajar/biasa, atau mati karena syahid dalam pertempuran ataukah ia mati karena bunuh diri. Jika status si mayat adalah seorang muslim maka wajib dimandikan, walaupun kewajiban memandikannya bagi seorang Muslim adalah sunnah muakkad, artinya jika sudah terdapat seseorang yang memandikan maka gugurlah kewajiban Muslim yang lainnya. Kalau

${ }^{5}$ Cermati, al-Bukhari, Abu Abdullah Muhammad bin Ismail, Shahih al-Bukhari (Riyadh: Baitul Afkar alDauliyah, 1998), juz IV, h. 461. Abu Husein Muslim alHajaj al-Qusyairi, Shabih Muslim (Riyadh: Baitul Afkar al-Dauliyah, 1998), juz XI, h.125 dan Abu Abdullah Ahmad bin Hambal, Musnad Imam Ahmad ibn Hambal (Beirut: Dar al-Fikr, 1994), juz XVIII, h.32.

${ }^{6}$ Cermati Abu Abdullah Muhammad bin Yazid al-Qazwaini, Sunan Ibn Majab (Lebanon: Darul Qutb alIlmiyyah, tth), juz IV, h. 364. 
mayatnya seorang yang kafir tidak wajib dimandikan. ${ }^{7}$ Meskipun demikian Imam Syafii membolehkan untuk memandikan mayat seorang yang kafir, karena menurut beliau perbuatan memandikan mayat tersebut bukanlah termasuk ke dalam ibadah tetapi hanya sekedar untuk menjaga kebersihan (للنظافة)

Sedangkan Imam Malik berbeda pendapat dengan Imam Syafii, beliau berpendapat bahwa seorang Muslim tidak boleh memandikan mayat yang kafir dan tidak pula menguburkannya. Imam Al-Tsaur dan Imam Abu Hanifah dan pengikutnya sependapat dengan Imam Syafii. Argumentasi yang mereka kemukakan adalah karena "adanya perintah nabi kepada para sahabat untuk memandikan pamannya (yang bukan Muslim) sewaktu pamannya meninggal dunia".

Jika mayat itu kematiannya karena gugur di medan jihad (syahid), maka ia tidak perlu dimandikan, karena begitulah arahan yang diberikan oleh nabi. ${ }^{10}$ Hal tersebut dapat kita rujuk kepada sabda beliau yang menegaskan :

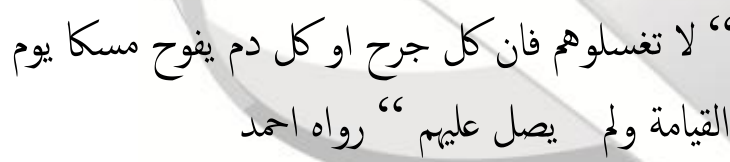

Jangan kalian mandikan mereka, karena sesungguhnya luka dan darah mereka yang mengalir ketika pertempuran akan memberi kesaksian di hari kiamat, (HR.Ahmad).

Sedangkan mayat pelaku bunuh diri, baik karena sebab sebab tertentu ataupun karena bom bunuh diri dapat kita rujuk kepada hadis berikut :

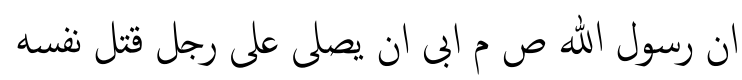

7 Sayyid Sabiq, Fiqh al-Sunnah, jilid 1, (Beirut, Dar al-Fath li al-I'lam al-Araby, 1990), h. 357

${ }^{8}$ Cermati Abdur Rahman al-Jaziry, al-Figh ala Mazabibil Arba'ah, juz I, ( Beirut, Dar al-Fikr, 1990), h.503-504.

30

9 Al-Jaziry, al-Fiqh ala Marabibil Arba'ah,...., h.

${ }^{10}$ Sayyid Sabiq, Fiqh Sunnah ....., h. 368
Sesungguhnya Rasulullah saw menolak untuk menshalatkan orang yang membunuh dirinya sendiri

Ulama berbeda pendapat dalam memberikan penilaian tentang kesahihan hadis ini, ada yang menilainya sahih dan ada pula yang mengatakan tidak sahih. Yang menilainya sahih berpendapat bahwa tidak boleh menshalatkan orang yang bunuh diri, tapi tidak mempersoalkan tentang memandikannya. Yang berpendapat hadisnya tidak sahih maka mayatnya diperlakukan seperti Muslim biasa artinya memperbolehkan menshalatkan orang yang bunuh diri meskipun ia masuk neraka. Mereka berargumentasi dengan hadis yang menjelaskan :

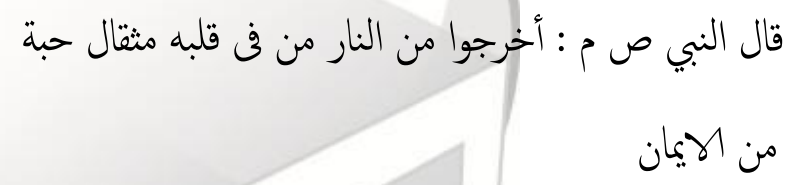

Nabi Muhammad saw menyatakan bahwa dikeluarkan dari neraka siapa saja yang di dalam hatinya masih ada rasa iman meskipun hanya sebesar atom.

Yang jelas mereka ini telah melakukan dosa besar, terlepas dari pendapat apakah pelaku dosa besar masih Muslim ataukah sudah kafir. Terkait dengan pelaku teror/terduga pelaku teror apakah statusnya Muslim ataukah kafir maka diperlukan jawaban teologis tentang hal ini.

Dengan demikian dapat kita refleksikan bahwa dalam konteks kemanusiaan tidak ada larangan yang tegas, artinya boleh saja untuk memandikan mayat pelaku atau terduga pelaku teror, tanpa mempersoalkan apakah dia muslim ataukah dia kafir, minimal perbuatan memandikan tersebut untuk menjaga kebersihan lingkungan seperti pendapat Imam Syafii, al-Tsaur Abu Hanifah dan pengikutnya.

Setidaknya argumentasi yang dapat diajukan adalah al-Quran surat al-Mursalat/77 : 25-26 : 


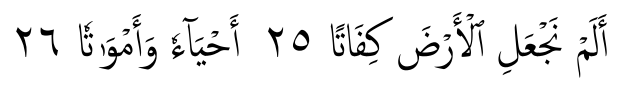

Bukankah Kami menjadikan bumi (tempat) berkumpul orang-orang hidup dan orang-orang mati

Tentang mengkafani, mengiringi dan menguburkannya sama saja halnya dengan memandikan, semuanya termasuk dalam persoalan kepatutan dan masalah muamalah dunyawiyyah. Ada kaidah fikih yang dapat dipegangi dalam hal ini :

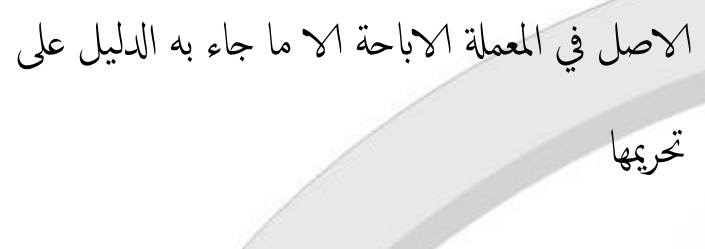

Pada dasarnya dalam bidang muamalah dunyawiyyah/kemanusiaan kita boleh saja melakukan sesuatu sepanjang tidak ditemukan dalil yang mengharamkan/ melarangnya.

Tidak ditemukan dalil yang tegas (sharih) yang melarang untuk memandikan, mengafani, mengiringi dan menguburkan mayat pelaku atau yang diduga pelaku teror. Yang ada hanya dalil yang memberikan arahan bagaimana cara harus memandikan, mengafani, mengshalatkan, mengiringi, dan menguburkan mayat. Sedangkan untuk menshalatkannya, karena shalat itu adalah perbuatan ibadah maka jika mayat itu non Muslim maka tidak boleh dishalati, ${ }^{11}$ Orang munafikpun tidak dishalati meskipun mereka telah bersyahadat. ${ }^{12}$

11 Arahan nabi adalah bahwa mayat yang dishalati itu ialah manakala ia ditenggarai pada masa hidupnya mengucapkan syahadatain (Muslim), terlepas dari ia pelaku dosa besar ataupun ahli bid'ah. Hal ini didasarkan pada hadis beliau :

قال النبى ص م صلو ا من قال لا اله الا الله

12 Hal ini didasarkan pada penegasan ayat alQuran surat al-Taubah/9:84

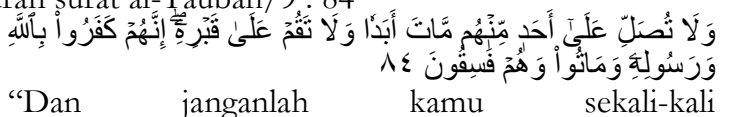
"Dan janganlah kamu sekali-kali antara mereka, dan janganlah kamu berdiri (mendoakan) di kuburnya. Sesungguhnya mereka telah kafir kepada Allah dan Rasul-Nya dan mereka mati dalam keadaan fasik"
Sedangkan mereka yang mati karena bunuh diri Ulama berbeda pendapat tentang hukum menshalati mereka. Penyebab perbedaan pendapat muncul adalah karena ada riwayat yang berbeda dan perbedaan penilaian terhadap hadis. ${ }^{13}$ Hanya perlakuan terhadap mayat saja yang berbeda. Jika mayat tersebut kematiannya katena syahid di medan perang maka ia dikafani dengan pakaian yang melekat pada dirinya dan tidak perlu dishalatkan. Hal ini didasarkan pada hadis yang menjelaskann bahwa :

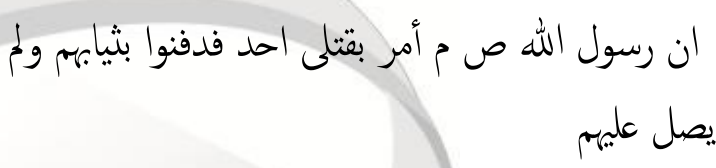

Meskipun al-Hassan dan Said bin Musayyab menyatakan bahwa setiap mayat Muslim itu sebaiknya dimandikan, karena boleh jadi mayat tersebut dalam keadaan berhadas besar (junub) yang tidak diketahui oleh yg lain.

Begitu juga mereka yang meninggal ketika sedang berihram, perlakuan terhadap mereka sedikit agak berbeda, mereka harus dimandikan dengan air bersih dan air bidara, dikafani dengan kedua kain ihramnya, kepalanya tidak boleh ditutupi,

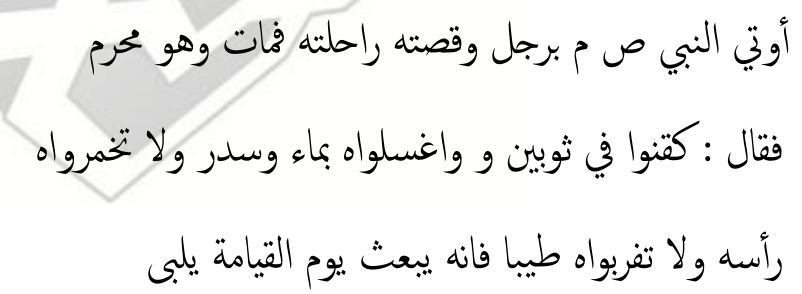

Dibawa menghadap Nabi, mayat seorang laki-laki yang jatuh dari kendaraannya padahal ia sedang berihram. Kata Nabi : mandikanlah dia dengan air

13 Ada hadis yang menjelaskan bahwa :

ان رسول الله ص م أبى ان يصلى على رجل قتل نفسه

Rasulullah saw menolak untuk menshalatkan orang yang membunuh drinya sendiri. Hadis lain menjelaskan bahwa, sepanjang orang tersebut ada tergores dalam hatinnya iman meskipun hanya sebesai atom ia akan dikeluarkan dari api neraka, kata nabi :

قال النبي ص م ـ اخرجو ا من النار في قلبه مثقال حبة من الايمان 
bersih dan air bidara, kemudian kafani dengan kedua kain ihramnya, jangan tutupi kepalanya, jangan beri wewangian, karena dia nanti di hari kiamat dibangkit dalam keadaan bertalbiyah.

\section{Pengelolaan Anak Korban Terorisme}

Pemeliharaan anak pada dasarnya menjadi tanggungjawab kedua orang tuanya. ${ }^{14}$ Pemeliharaan dalam hal ini meliputi berbagai hal, yaitu dalam masalah ekonomi, pendidikan dan segala sesuatu yang menjadi kebutuhan pokok anak. ${ }^{15}$ Dalam konsep Islam tanggung jawab ekonomi berada di pundak suami sebagai kepala rumah tangga, meskipun tidak menutup kemungkinan istri dapat membantu suami dalam memenuhi kebutuhan ekonomi. ${ }^{16}$

Dalam kitab-kitab fikih hal ini masuk dalam bahasan hadlanah, yang berarti al-janbdi samping atau berada di bawah ketiak, atau meletakkan sesuatu dekat tulang rusuk seperti menggendong atau meletakkan dalam pangkuan. Maksudnya adalah merawat dan mendidik seseorang yang belum mumayyiz atau karena mereka belum dapat

\footnotetext{
${ }^{14}$ Cermati ayat al-Quran surat al-Baqarah/2 : 233 yang menyatakan "

Dan kewajiban ayah memberi makan dan pakaian kepada para ibu dengan cara ma'ruf. Seseorang tidak dibebani melainkan menurut kadar kesanggupannya. Janganlah seorang ibu menderita kesengsaraan karena anaknya dan seorang ayah karena anaknya, dan warispun berkewajiban demikian.

${ }^{15}$ Cermati juga al-Quran surat al-Thalaq/65 : 7, yang menyatakan :

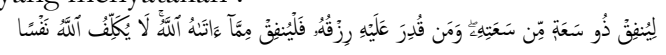

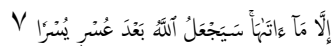

Hendaklah orang yang mampu memberi nafkah menurut kemampuannya. Dan orang yang disempitkean rezekinya hendaklah memberi nafkeah dari harta yang diberikan Allah kepadanya. Allah tidak memikulkan beban kepada seseorang melainkan sekedar apa yang Allah berikan kepadanya. Allab kelak akan memberikan kelapangan sesudah kesempitan

16 Ahmad Rafiq, Hukum Islam di Indonesia, (Jakarta, Raja Grafindo Persada, 2003), h.235.
}

memenuhi/mengerjakan semua keperluannya sendiri. ${ }^{17}$

Jadi hadlanah itu adalah menjaga anak yang belum bisa merawat dan mengatur dirinya sendiri, serta belum mampu menjaga diri dari hal-hal yang membahayakan dirinya, ${ }^{18}$ yang menurut Zahabi termasuk mendidik dan memperbaiki kepribadiannya.

Jadi para ahli fikih menjelaskan tentang badlanab ini mencakup pemeliharaan, menyediakan sesuatu yang menjadikan kebaikan baginya, dan menjaganya dari sesuatu yang menyakiti dan merusaknya, mendidik jasmani, rohani dan akalnya agar ia mampu berdiri sendiri menghadapi hidup dan memikul tanggung jawabnya. ${ }^{19}$

Dalam Kompilasi Hukum Islam pasal 1 huruf g disebutkan bahwa:

"Pemeliharaan anak atau hadlanah adalah kegiatan mengasuh, memelihara dan mendidik anak hingga dewasa atau mampu berdiri sendiri”.

Dalam kitab-kitab fikih, Perkawinan, Kompilasi Hukum Islam dijelaskan bahwa yang bertanggung jawab untuk hadlanab ini adalah kedua orang tuanya, dan manakala kedua orang tuanya tidak dapat menunaikan kewajibannya, tanggung jawab tersebut berpindah kepada karib kerabatnya, dan jika karib kerabatnya tidak mampu tentu berpindah menjadi bagian dari tanggung jawab masyarakat/negara. ${ }^{20}$

Ketika pihak-pihak yang bertanggung jawab tersebut tidak dapat memenuhi tanggung jawabnya karena ketidakmampuan dan ketidakberdayaan ekonomi maka untuk keperluan tersebut dapat diambilkan dari dana

17 Andi Syamsu Alam, M.Fauzan, Hukum Pengangkatan Anak Perspektif Islam, (Jakarta, Pena Media, 2008), h.114.

${ }^{18}$ Khairul Amri Harahap, Faisal Shaleh, Shabih Fikih Sunnah, (Jakarta, Pustaka Azzam, 2007), h. 666.

${ }^{19}$ Sayyid Sabiq, Fiqh Sunnah, jilid 8, (Bandung, PT Al-Ma'arif, 1980), h. 160.

20 Cermati UU No. 1 tahun 1974 pasal 41, 43,dan 47, KHI pasal 1, 80, 105, dan 156 
zakat (asnaf fakir - miskin - gharimin -dan ibn sabi), bahkan jika itu untuk menjaga kemaslahatan umum/umat untuk kepentingan pengelolaan korban teror ini juga dapat diambilkan dari dana zakat (asnaf muallaf dan sabilillab).

Hanya saja dalam kitab-kitab fikih dijelaskan bahwa terdapat perbedaan pendapat di kalangan ulama terkait dengan kewajiban hadlanah ini. Kalangan Hanafiyah berpendapat itu berlangsung sampai anak berumur 7 tahun untuk anak laki-laki dan 9 tahun untuk anak perempuan. Kalangan Malikiyyah menyatakan untuk anak laki-laki berakhir ketika ia telah baligh/dewasa, dan untuk anak perempuan baru berakhir kalau ia sudah menikah. Sedangkan Syafiiyyah dan Hanabilah berpendapat bahwa pengasuhan itu berakhir ketika anak sudah berumur $7 / 8$ tahun. ${ }^{21}$

Dengan demikian dapat disimpulkan bahwa pengelolan anak dan keluarga korban terorisme sesungguhnya adalah menjadi tanggung jawab bersama, walaupun yang lebih utama yang bertanggungjawab untuk ini adalah karib kerabatnya. Ketika karib kerabatnya tidak dapat memikulnya maka menjadi tanggung jawab bersama bahkan juga menjadi tanggung jawab negara.

\section{Menyembunyikan Pelaku}

Sebelum menjawab boleh tidaknya menyembunyikan pelaku atau terduga pelaku teror, ada baiknya dijelaskan dulu untuk apa pentingnya menyembunyikan pelaku. Jika kepentingannya adalah untuk menjaga dan melindungi hak-haknya(HAM)-nya dan supaya tidak diperlakukan semena-mena, tapi supaya diperlakukan sesuai dengan hukum yang adil dan berperikemanusiaan maka hal tersebut tentu saja diperbolehkan. Tapi jika kepentingannya hanya sekedar untuk memberi perlindungan agar dia bisa tetap hidup, dan

\footnotetext{
${ }^{21}$ Sayyid Sabiq, Figh Sunnah, ..... h. 173
}

bisa jadi mengulangi perbuatannya tentu saja tidak boleh.

Hanya saja, kekerasan mengatasnamakan terorisme tumbuh menjadi fakta yang mengisi ruang berita di media massa. Pelaku terorisme menjadi konsumsi publik bahkan disiarkan secara live. Menurut Adam, hal ini didukung oleh kondisi sosial-politik pasca reformasi tahun 1998 yang membuka ruang publik yang selama ini terkunci rapat. Selanjutnya dalam Adam, relasi antara media massa dan terorisme dapat dideskripsikan melalui relasi simbiosis mutualisme di mana kedua belah pihak memerlukan satu sama lain dalam sebuah hubungan yang saling menguntungkan. Media massa memosisikan informasi tidak lebih dari sebuah transaksi yang ditujukan untuk memenuhi kebutuhan konsumen di pasar informasi. Karenanya, informasi yang sensasional selalu mendapat tempat dalam ruang berita media massa saat ini. Di sisi lain, tindakan kekerasan yang dilakukan oleh kelompok teroris merupakan fakta sosial yang dapat diolah menjadi fakta media. Fakta tersebut merupakan komoditas bernilai tinggi oleh media massa ${ }^{22}$

Dalam perspektif fikih, boleh tidaknya menyembunyikan pelaku atau terduga pelaku teror tersebut sangat tergantung dari maslahah dan mafsadah apa yang bisa muncul dari perbuatan menyembunyikan tersebut. Maslahah dan mafsadah inilah yang menjadi inti dari tujuan Tuhan (maqashid al-syariab) untuk menurunkan ajaran Islam. ${ }^{23}$ Bahkan dalam kitab fikih kita menemukan penjelasan bahwa berbohongpun boleh dilakukan jika mengandung unsur kebaikan/kemaslahatan.

22 Sukarno, Adam W., "Dilema Peliputan Terorisme dan Pergeseran Pola Framing Berita Terorisme di Media Massa", Jurnal Ilmu Sosial dan Ilmu Politik, Vol. 14, No. 3, 2011, h. 333-348.

${ }_{23}^{3}$ Jassser Auda, Maqashid as-Syari'ah as Philosopy of Islamic Law : A System, (London, International Institute of Islamic Thought, 2008), h. 2-3 
Pendapat ini didasarkan pada hadis Nabi yang menyatakan :

$$
\begin{aligned}
& \text { قال النبي ص.م. لا يصلح الكذب ال في ثلاث : يحدث } \\
& \text { الرجل امرأته والكذب في الحرب والكذب ليصلح بين } \\
& \text { الناس • رواه الترميذى وحسنه الالبانى }
\end{aligned}
$$

Nabi saw. Bersabda: Berbuat bohong itu tidak boleh karena tidak mengandung kebaikan kecuali dalam tiga hal : suami berbohong kepada isterinya (demi kelanggengan rumah tangganya), tentara berbohong pada musuh (demi melindungi pasukan dan negaranya), seseorang berbohong untuk kebaikan orang lain. (HR. Turmuzi dan hadisnya dianggap hasan oleh Albany)

Jika maslahahnya nyata dan bersifat umum (maslabah ammah) artinya untuk :kepentingan orang banyak bukan untuk kepentingan pribadi maka perbuatan tersebut menjadi boleh bahkan mungkin harus/wajib dilakukan. Akan tetapi jika madaratnya nyata maka tentu saja tidak boleh dilakukan bahkan mungkin terlarang/haram untuk dilakukan.

Khalifah Umar bin Khattab pernah menyatakan bahwa : "kemaslahatan umat lebih diutamakan ketimbang dengan kemaslahatan individu". 24

Atas dasar penjelasan hal di atas maka persoalan menyembunyikan pelaku/terduga pelaku teror menjadi lebih jelas. Manakala tujuan menyembunyikannya adalah untuk kepentingan penegakan hukum yang adil dan berperikemanusiaan atau menjaga HAM maka tentu saja diperbolehkan karena hal ini sejalan dengan maqashid al-syariah - tidak hanya sekedar pada level dibutuhkan (hajjiyat) tapi bisa sampai pada level dlaruriyyat dimensinya adalah li hifdhi al-nafsi dalam arti menjaga dan

24 Amir Syarifuddin, Pembaharuan Pemikiran Dalam Islam, (Bandung, Angkasa Raya, 1993), h. 97. melindungi martabat kemanusiaan dan menjaga dan melindungi hak asasi mansia. ${ }^{25}$

Akan tetapi jika maksud dan tujuan menyembunyikan tersebut hanyalah sekedar memberikan rasa aman kepada pelaku/terduga pelaku dari kejaran aparat bukan untuk mendapatkan unsur dan perilaku keadilan maka mafsadah/resikonya tentu lebih besar dari maslahatnya, karenanya tidak boleh dilakukan.

\section{Autopsi Jenazah Pelaku/Terduga Pelaku Teror}

Upaya perlindungan hukum terhadap autopsi jenazah pelaku teror juga semesti dijamin oleh undang-undang. Dalam Nogroho, autopsi teorisme atau bahkan korban salah tangkap perlu didudukkan mekanismenya. Bahkan tidak hanya itu Pemberantasan Tindak Pidana Terorisme segera diamandemen dan perlu memperhatikan

Remidium dengan prinsip Ultimum mengintegrasikan pendekatan penal dan non-penal. Hal ini dikarenakan pendekatan non-penal memegang peranan yang sangat penting dalam pemberantasan tindak pidana terorisme, terutama terhadap tindak pidana terorisme ${ }^{26}$.

Di samping itu, autopsi bahkan pembedahan yang dilakukan pada mayat atau pemeriksaan post mortem untuk mengetahui sebab kematian para pelaku harus berjalan dalam asas kemanusiaan. Autopsi itu ada dua macam ada autopsi forensik/kehakiman ada autopsi klinis ${ }^{27}$. Tentu yang dimaksud autopsi pada tulisan ini adalah autopsi forensik, sebagaimana menurut Dunlop ini diperlukan

${ }^{25}$ Jasser Auda, Maqashid as Syari'a ....., h. 21-23

${ }^{26}$ Nugroho, Gito, "Upaya Perlindungan Hukum Terhadap Korban Salah Tangkap Oleh Tim Detasemen Khusus 88 Dalam Kasus Dugaan Terorisme", Jurnal Poenale, Vol. 5, No. 4, 2017, h. 12

${ }_{27}$ Hassan Shadily, Ensiklopedi Indpnesia, (Jakarta, Ikhtiar Baru van Hoeve, 1989), h.332 
dalam hal kematian tidak wajar atau kematian yang sebabnya mencurigakan ${ }^{28}$.

Sebelum menjelaskan bagaimana pandangan fikih terkait dengan hukum autopsi terhadap mayat pelaku/terduga pelaku teror, ada baiknya kita fahami dulu apa perlunya dilakukan autopsi. Autopsi menurut Holcomb tentu dibutuhkan untuk pembuktian kebenaran tentang penyebab kematian seseorang, apakah kematiannya wajar ataukah karena sebab sebab lain yang mencurigakan, mungkin karena penganiaayaan atau karena direkayasa untuk dibunuh $^{29}$. Metode ini telah diterapkan pada operasi tentara Amerika Serikat dalam mengidentifikasi kasus teroris yang marak di Negara ini pasca 11/9. Autopsi tersebut harus dilakukan oleh mereka yang ahli di bidangnya/kaum profesional. Perbuatan membuktikan tersebut ialah meyakinkan Hakim/pihak lain tentang kebenaran dalil atau dalil-dalil yang dikemukakan dalam satu persengketaan. ${ }^{30}$ Pembuktian itu diperlukan manakala apa yang dikemukakan dibantah oleh pihak lain, tidak diterima oleh pihak lain, apa yang tidak dibantah tidak perlu dibuktikan. Dalam fikih Islam pembuktian tersebut dinamakan dengan al-bayyinah.

Ibnul Qayyim al-Jauziyah mengatakan bahwa :

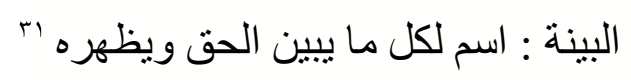

Pembuktian itu adalah nama untuk tiap tiap yang menyatakan kebenaran dan menjelaskannya

${ }^{28}$ Dunlop, W H, and Smith, H P., "Who Did It? Using International Forensics to Detect and Deter Nuclear Terrorism", Arms Control Today, Vol. 36, No. 8, October 1, 2006, h. 5.

${ }^{29}$ Holcomb, John B., et al., "Causes of Death in US Special Operations Forces in The Global War on Terrorism: 2001-2004", Annals of Surgery, Vol. 245, No. 6, 2007, h. 986.

30 R.Subekti, Hukum Pembuktian, Jakarta, Pradnya Paramita, 1975), h. 5

31 Muhammad Salam Mazkur, al-Qadla' fil Islam, (Mesir, Dar Nahdlah al-“Arabiyyah, t.th.),
Sedangkan Hasbi As Shiddieqy menyatakan bahwa pembuktian itu adalah segala yang dapat menampakan kebenaran, baik dia merupakan saksi atau sesuatu yang lain. ${ }^{32}$ Dengan demikian dapat difahami bahwa membuktikan tersebut adalah menyatakan kebenaran. Dalam kaitannya dengan autopsi pelaku/terduga pelaku teror tentu saja adalah untuk mengetahui kebenaran penyebab kematiannya, apakah terdapat pelanggaran HAM atau tidak. Ini diperlukan mungkin oleh keluarga ataupun oleh masyarakat.

Dalam satu negara sangat diperlukan suatu lembaga peradilan untuk menyelesaikan persengketaan dan memutuskan hukum yang harus ditegakan oleh pemerintah dan masyarakat, karena urusan menyelesaikan persengketaan yang terjadi antara anggota masyarakat adalah suatu urusan yang sangat penting dan utama dalam negara yang demokratis yang menghendaki tegaknya keadilan dan kebenaran.

\section{Kesimpulan}

Dalam pandangan fikih Islam autopsi (forensik) dapat dilakukan, dan hasilnya berfungsi sebagai alat bukti, yang dalam hukum pembuktian dalam Islam bisa dimasukan ke dalam bukti "saksi", yaitu orang yang didengar keterangannya, termasuk di dalamnya keterangan ahli. Dalam hal ini banyak ayat al-Quran yang memerintahkan untuk memberikan kesaksian ini terutama bagi mereka yang sanggup memberikannya. Di antara ayat- ayat tsb adalah :

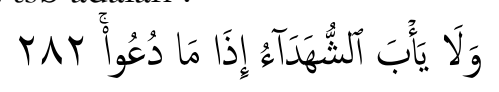

Janganlah saksi-saksi itu enggan (memberi keterangan) apabila mereka dipanggil;

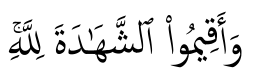

32 TM Hasbi As Shiddieqy, Falsafab Hukum Islam, Jakarta, Bulan Bintang, 1975), h. 139 
dan hendaklah kamu tegakkan kesaksian itu karena Allah.
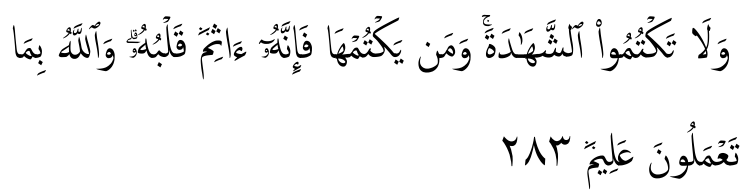

Dan janganlah kamu (para saksi) menyembunyikan persaksian. Dan barang siapa yang menyembunyikannya, maka sesungguhnya ia adalah orang yang berdosa hatinya; dan Allah Maha Mengetahui apa yang kamu kerjakan

Dengan demikian dapatlah disimpulkan bahwa autopsi (forensik) tersebut boleh bahkan mungkin harus dilakukan bila punya alasan yang kuat, karena dia akan berfungsi untuk mengungkap atau membuktikan kebenaran.

\section{Daftar Pustaka}

\section{Buku Teks}

Abdur Rahman al-Jaziry, al-Fiqh ala Mazabibil Arba'ah, juz I, (Beirut: Dar al-Fikr, 1990)

Ahmad Rafiq, Hukum Islam di Indonesia (Jakarta: Raja Grafindo Persada, 2003)

Amir Syarifuddun, Pembaharuan Pemikiran Dalam Islam (Bandung: Angkasa Raya, 1993).

Andi Syamsu Alam, M.Fauzan, Hukum Pengangkatan Anak Perspektif Islam (Jakarta: Pena Media, 2008).

Hassan Shadily, Ensiklopedi Indpnesia (Jakarta: Ikhtiar Baru van Hoeve, 1989)

Jassser Auda, Maqashid as-Syari'ah as Philosopy of Islamic Law: A System (London: International Institute of Islamic Thought, 2008)

Khairul Amri Harahap, Faisal Shaleh, Shabih Fikih Sunnah (Jakarta: Pustaka Azzam, 2007)

Muhammad Salam Mazkur, al-Qadla' fil Islam (Mesir: Dar Nahdlah al-“Arabiyyah, t.th).
Sayyid Sabiq, Fiqh al-Sunnah, jilid 1, (Beirut: Dar al-Fath li al-I'lam al-Araby, 1990)

R.Subekti, Hukum Pembuktian (Jakarta: Pradnya Paramita, 1975)

TM Hasbi As Shiddieqy, Falsafah Hukum Islam (Jakarta: Bulan Bintang, 1975)

Yusuf al-Qaradlawy, Membumikan Syariat Islam, Keluwesan Aturan Ilabi Untuke Manusia (Bandung: Arasy Mizan, 2003)

\section{Jurnal}

Asnawi, Habib Shulton, "Hak Asasi Manusia Islam dan Barat (Studi Kritik Hukum Pidana Islam dan Hukuman Mati)", Jurnal Supremasi Hukum.1.1 (2012).

Dunlop, W H, and Smith, H P., "Who Did It? Using International Forensics to Detect and Deter Nuclear Terrorism", Arms Control Today, Vol. 36, No. 8, October 1, 2006.

Holcomb, John B., et al., "Causes of Death in US Special Operations Forces in The Global War on Terrorism: 20012004", Annals of Surgery, Vol, 245, No.6, 2007.

Nugroho, Gito, "Upaya Perlindungan Hukum Terhadap Korban Salah Tangkap Oleh Tim Detasemen Khusus 88 Dalam Kasus Dugaan Terorisme", Jurnal Poenale, Vol. 5, No. 4, 2015

Rokhmad, Abu, "Radikalisme Islam dan Upaya Deradikalisasi Paham Radikal", Walisongo: Jurnal Penelitian Sosial Keagamaan, Vol. 20, No. 12012.

Sukarno, Adam W., "Dilema Peliputan Terorisme dan Pergeseran Pola Framing Berita Terorisme di Media Massa", Jurnal Ilmu Sosial dan Ilmu Politik, Vol. 14, No. 3, 2011

Umar, Ahmad Rizky Mardhatillah. "Melacak Akar Radikalisme Islam di Indonesia", Jurnal Ilmu Sosial dan Ilmu Politik, Vol.14, No. 2, 2010. 